\title{
MEDIA, TERRORISM AND NATIONAL SECURITY IN NIGERIA’S FOURTH REPUBLIC
}

DALHATU, MUSA YUSHA’U PhD (․usadalhat03@gmail.com)

DEPARTMENT OF POLITICAL SCIENCE, FEDERAL UNIVERSITY, LAFIA, NASARAWA STATE, NIGERIA, ERUNKE, CANICE ESIDENE PhD (를e72@ gmail.com) AND IDAKULA, AMOS RHODA

DEPARTMENT OF POLITICAL SCIENCE, NASARAWA STATE UNIVERSITY, KEFFI, NASARAWA STATE, NIGERIA

DOI: $10.31364 / S C I R J / v 7 . i 4.2019 . P 0419640$

http://dx.doi.org/10.31364/SCIRJ/v7.i4.2019.P0419640

\begin{abstract}
Nigerian state, just like many other states in the world today, has suffered and continues to experience the devastating effects of terrorist activities with its untold consequences on socio-economic, political and cultural lives of the people. Since the returned to democracy in 1999, Nigeria has been grappling with the phenomenon of terrorism such as the Boko Haram terrorism that posed a serious challenge to national security. This paper, though based on social identity theory, examined the spate of terrorism, national security challenges and the role of media and democratic sustainability in Nigeria's Fourth Republic. In carrying out the study, secondary data were explored and content analysis applied. The study thus revealed that insecurity and terrorism are inimical to democratic sustainability and development of Nigeria. Systemic corruption, malicious media report, ethno-religious, political and economic-based violence, including pervasive illiteracy, unemployment and poverty are some of the pre-disposing factors and challenges of national security in Nigeria's Fourth Republic. To stem the tide of terrorism and insecurity in Nigeria, there must be ethical re-orientation in media practice, a genuine and inclusive fight against corruption, pervasive unemployment and poverty, as well as addressing the issues of ethno-religious, political and economic-based violence with robust improvement in national security architecture.
\end{abstract}

Key Words: Democratic Sustainability, Media, National Security, Terrorism, Nigerian, Fourth Republic

\section{Introduction}

The Nigerian state and indeed many other African states have been over burdened with terrorism and its devastating impacts in the last decade. To many public analysts and critics, terrorism has had very dangerous implications on the socio-economic, political and cultural lives of the people. Further arguments on the effects of terrorism, especially those coming from the point of view of intelligentsias and scholars point to the fact that terrorism in its current operations knows no bound, color, race, religion and indeed, political affiliations. The problem of terrorism therefore traverses primordial interests and boundaries and finds expression on the global space, irrespective of gender, creed or any other political persuasions. Thus, the wave of terrorism as it were has assumed an alarming dimension and its impact, especially in sub-Saharan Africa has very huge security implications. It is therefore a common phenomenon to talk about terrorism and the various nomenclatures associated with religious sects that do operate in several locations of the world. Such countries, for example, include but not limited to Mali, Somalia, Kenya, Niger, Cameroon, Nigeria, Afghanistan, Iraq, Syria, France and the United States of America.

In Nigeria, the spate of terrorist attacks orchestrated by the Boko Haram sect is well known. The threat of this dreaded sect, especially in most parts of Nigeria's North-East geo-political zone has literally grounded the Nigerian state. The security challenge posed by the sect has constituted a huge problem not only to the Federal Government of Nigeria, but has also been a major concern to neighboring nations such as Niger, Cameroon, Chad and Benin Republic. Nigeria's diplomatic relations with some of these countries revolves around how to mobilize resources, both human and material, to contain with not only the menace of terrorism, but also how to mitigate the accompanying national security challenges. 
It is on this basis that, Abimbola and Adesote (2012) have argued that since Nigeria's return to civil rule in 1999, the nation had grappled with terrorism and terrorist activities in large proportions. At this point, very obvious distinctions can be made. The distinction is in terms of the old trend of Niger-Delta terrorism and the new angle of Boko Haram activities. The two seem to have different characteristics in terms of the roles they play. Again, while the former appears to have a human face, the latter is seemingly faceless and hence, the tendency to curtail its activities since inception has been largely difficult till now. As earlier pointed out by Abimbola and Adesote (2012) Nigeria has over the years, especially within the period of this democratic experimentation, been battling with terrorism across the six geo-political zones of the country. To be sure, the spate of bomb blasts, kidnapping, pipeline vandalism and other forms of criminalities in recent times in various parts of the country are emerging trends of domestic terrorism.

Historically, the problem of terrorism as it relates to Boko Haram insurgency is not the first major group attacks that have bedeviled the Nigerian state. In this direction, Awortu (2015) has claimed that different sects or groups had risen in Nigeria with little or real militancy ideologies and mode of operations in prosecuting their different objectives. They include the Maitatsine Islamic fundamentalist sect in North-East and North-West Nigeria, Odua People's Congress (OPC) from the Yoruba ethnicity in South-West Nigeria, Bakassi Boys and Movement for the Actualization of Sovereign State of Biafra (MASSOB) from the Igbo ethnic extraction in the South-East Nigeria and the Niger-Delta militants from the minority ethnic conglomerations in the nation's South-South geopolitical zone. The Boko Haram terrorist attacks however appears to be a recent phenomenon, especially during the early periods of the death of Nigeria's former President Umaru Musa Yar'Adua. For the purpose of understanding however, the focus of this research will tilt more to terrorism as it relates to Boko Haram Islamic sect and the role of media in the crisis. The reason is the increasing relevance of the sect and how it has posed profound security concern not only to Nigeria; but to the rest of the world. This is not however intended to undermine the relevance of other terrorist enterprises such as the Niger-Delta situation and other boisterous groups in Nigeria. In the case of Boko Haram, Walker (2012) alluded that the sect grew out of radical Islamic youths who worshipped at the Al-Haji Muhammadu Ndimi Mosque in Maiduguri, capital of Borno state in the 1990's. Extant history has it that the leader of the sect at the time, Mohammed Yusuf began as a leader and preacher in the youth wing of Shababul Islam of Ahl-Sunnah, a Salafi group. His literal interpretation of the Qur'an led him to advocate that certain aspects of western education such as evolution, the theory of development of the universe and critical elements of geography and chemistry are contradictory to the Holy Book. In his thinking, he posited that some of these things are atrocious and so, must be forbidden and considered sinful (Walker, 2012).

The Nation (2011) reported that Boko Haram in Nigeria snow-balled into national menace after the 2011 general elections. The Northern Governors who had relationship with the sect began to withdraw their patronages and eventually abandoned them to their fates. Most scholars and analysts tend to subscribe to the opinion that terrorism is a political expression and not a criminal act. As a result, they agreed that terrorists across the world (Nigeria inclusive) have a common adversary in the status quo and powers that be represented by the regime in power. In their view, the major objective of terrorists is to disrupt the structure of governance represented by the status quo or dismantle the regime in power so as to impose their own value system on the rest of the society. This they do (including Nigeria's Boko Haram Islamic sect) using lethal weapons such as rocket propelled grenades (RPGs), anti-tank missiles, Improvised Explosive Devices (IEDs), surface-to-air missiles, armored tanks, A-K47 assault rifles, as well as machetes daggers for the purpose of meting out mayhem to the Nigerian state with attendant consequences (Gilbert, 2014).

The mass media is a critical stakeholder in the attainment of national security goal. Security agencies and media play different but complimentary roles in containing the acts of terror against the people. The connection between information as a tool and objective of achieving national security is so powerful that state must be concerned with those at the helm or who champions the provision of this tool called information to the citizenry in order to achieve homeland security. The media by virtue of being at certain vantage position among other groups in the society assume a frontline role in providing information on issues, government policies and actions, especially on security matters. So the media cannot afford to shrink back or shirk this responsibility. The inability of media to perform this responsibility with utmost sincerity, fairness and patriotism has been impeding on national security in Nigeria. Momoh (2016) opined that, the media must be insatiable in finding creative ways of gathering, processing and disseminating accurate and meaningful information in fulfilling the need for national security.

The paper therefore explored the role of media in relationship to terrorism and national security in Nigeria under the present dispensation and the security challenges threatening the sustainability of the Nigeria's nascent democracy. It however concludes with the way forward. 


\section{Theoretical Issues}

This study employs the social identity theory as a basis for the explanation of terrorism in Nigeria. Essentially, the social identity theory is important so much so that it provides useful insight to the understanding of the several identity issues that has plagued the Nigerian plural society over time in terms of insecurity. The relevance of this theory to any national discourse has been further amplified by scholars such as Brannan et al cited in Arena and Arrigo (2006). To these scholars, social identity theory captures the significant social phenomena and brings to bear a group's internally constructed social identity as well as the extent to which some of these groups instill consciousness in the minds and hearts of their members. The multiplier effects of this kind of social group orientation grows overtime and tends to increase the character of violence that can become a security challenge to a polity such as that of Nigeria and elsewhere.

The central thrust of this theory focuses on the way and manner in which people see themselves in terms of what tribe they belong, what religion they practice and most importantly, what geo-political zone they come from. One of the most critical issues in all of these sentiments is the ideological leaning of members of one group over the other. This increasing line of social divide has been the bane of the Nigerian social cohesion since the nation's independence in 1960. Interestingly, the argument is that the sustained postcolonial crisis expressed by groups over the years on how the nation should be structured to reflect diverse social interests is what has come to be manifested in form of Boko Haram terrorism or any other belligerent sects. In either case, the consequences can be very gravious, socially, economically and politically.

However, the notion of social identity theory was first systematically developed by scholars such as Tajfel and Turner. According to Tajfel and Turner (1985), the social identity theory is used to explain the psychological basis of intergroup discrimination in a society such as those of Nigeria. The theory purports that membership to social groups forms an essential aspect of a person's identity. To a large extent, most people tend to classify themselves and others into various social categories. For example, the categories could be organizational membership, religious affiliations, gender differences as well as age brackets. Social category in this sense gives the members of a structure of self-reference and group identity. Taking the argument further, Tajfel and Turner opined that a social category is a collection of individuals who perceive themselves to be members of the same category, share same emotional involvement in this common definition of themselves. They also achieve some degree of social consensus about the evaluation of their groups and membership of such groups. The theory of social identity holds that a person has no one 'personal self', but rather several selves that correspond to the increasing circles of group membership. Thus, different social contexts may trigger an individual to think, feel and act on the basis of his personal, familial or national levels of 'self'. The perception of social identity as being a subject matter of 'self' as propounded by Fajfel and Turner has been corroborated by most scholars such as Ashforth and Mael (1989); Agbiboa (2013). To these latter scholars, opined that the identity thesis manifests in three forms each of which is mutually reinforcing. Firstly, social identity is a perception of oneness with a group of person. Secondly, it involves the forming of in-groups and out-groups and, thirdly, social identity leads to activities that are congruent with the identity, support for institutions that embody the identity, stereotypical perception of others and self. It also finds expression in outcomes that are traditionally associated with group formation such as the one of Boko Haram terrorist groups.

Relating the theory of this study to the thesis, it can be unarguably alluded that aside from other social variables that constitutes the Nigerian problems, religion is quite critical as major pre-disposing factors bringing about Boko Haram terrorism. In Nigeria, for instance, religion remains a powerful source of individual and social group identity. The choice of religion in the analysis of the linkages of social identity in Nigeria is in view of the relevance it has in Nigeria's national life.

\section{Methodology}

This study uses the Expost-facto research design to unravel the relationship between mass media and terrorism/national security in Nigeria's Fourth Republic. Secondary and empirical data were obtained from published, unpublished and internet sources that addresses issues on terrorism and national security and the role of media. Content analysis was also adopted in analyzing the data gathered. The choice of this is based on the nature of the issue under study. According to Steve (2001) "content analysis enables researchers to sift through large volumes of data with relative ease in systematic fashion. It is also useful for examining trend and patterns of phenomenon in literatures".

\section{Security and Terrorism: Towards a Conceptualization}


The concept of security, just like terrorism, is a fluid concept in social science discourse. Hence, defies unanimity in terms of its exact meaning. Scholars, especially those with social science bias looks at the concept using different perspectives. Nwagboso (2012) for instance looks at security as an essential concept that has direct bearing with the alleviation of threats to cherished values, especially the survival of individuals or group aspirations. For the purpose of this research however, the above concept is rather restrictive and does not inculcate the aspirations of a system in relation to its external environment. In another dimension, Williams (2008) tends to share the same view with Nwagboso (2012) when he claimed that as an essential condition of survival, security finds expression on the factors of which Abraham Maslow referred to as hierarchy of needs. They include such variables as human needs, safety, selfesteem and confidence, freedom from danger and fear, doubt and intimidation of all kinds.

The general interest of this study is on internal security in relation to terrorism and the multiplier effect it has on democracy and external relations of the country. Terrorism is in this manner regarded as the unlawful use of violence and intimidation especially against civilians, in pursuit of political aims. The aim is to effect new political order as against the existing status qou. The Boko Haram terrorism seems to be the most dreaded in the history of Nigeria. Its effects on the internal security of the nation cannot be imagined.

Internal security of a nation on the other hand, is critical in its socio-economic and development processes. Therefore, the strategic importance of security at whatever level of definition becomes the sine quanon upon which the overall existence and survival of the system rest. The critical importance of national security in a state like Nigeria which has found herself enmeshed in the quagmire of terrorism over time has been carefully articulated by a security expert and public commentator, Max Gbanite. According to Gbanite (2001),

When our citizen's right to safety from all kinds of man-made threats is reduced considerably, the government will inherit an increase in foreign investments... most countries would like to be a trading partner to secure the lives and property of their citizens first before they themselves allow theirs to move into such territories.

The above quotation points to the idea earlier raised that internal security could be a function of external relations. This is to also say that insecurity orchestrated by terrorism is a minus on the nation's relations not only with her immediate neighbours, but also with the wider international community.

Drawing from the above, it can be said that Nigeria has experienced and has continued to face severe security challenges prior to 2007. Nonetheless, the increasing spate of terrorism and ethnic wrangling in the country and their continuous attacks on government institutions and structures as well as the people clearly underscores why Professor Bola Akinterinwa lamented viz:

...Security appointees have failed the president, Chief Olusegun Obasanjo. If we are to judge the current state of affairs in the country... Nigeria is in a state of lawlessness. It is a shame when the Attorney General of the Federation and Minister of Justice was killed so easily. The aggressive posturing of sectional groups like the O'odua Peoples Congress (OPC), armed robbery, paid assassins, kidnapping of foreigners, trafficking on drugs higher prices of commodities and indeed terrorism (emphasis added) are realities being faced in a country that requires urgent remedies (Akinterinwa, 2001).

\section{Security Challenges and Sustenance of Democracy in Nigeria}

As noted by the Nigeria's former military Head of State in one of his opening speeches in 2004 at the National Institute of Policy and Strategic Studies (NIPSSS) in Jos, General Abdulsalami Abubakar alluded, and very strongly too, that, Nigeria's greatest challenge is insecurity. To Abubakar (2004) cited in Okpaga, Ugwu and Eme (2012) claimed that:

....in addressing the challenge to the survival of democracy in Nigeria, it is pertinent to consider security issues and problems that have affected the attitude, confidence and cooperation of all groups and segments that make up the Nigerian federation. 
From the piece of quotation as presented above, Abubakar tends to be saying that moving the nation forward especially as it relates to the progress of the nation's democratic project, enhancing security at all levels is key. To Oyobode (2011) concurring with Abubakar's position on the imperative of national peace and security posits that "it is self-evident that without security, hardly is anything possible". He however warned that security should go beyond law and order and therefore encompassing meaningful existence for the generality of the populace. Aligning his views on the fact that meaningful existence is critical in security discourses as opined by Oyobode; Ezeola (2011) on his part claims that security means stability and continuing of livelihood, predictability of relationships and belonging to a social group.

On the contrary however, many contributors and critics such as Jegede (2011) in his book "Back to State of Nature" has looked at the possibilities and challenges of sustainable piece in an embattled democratic state like Nigeria. According to Jegede (2011) and Adehis (2011) the Nigerian leadership has the task and constitutional responsibilities to protect lives and properties by providing adequate security. Absence of security or the lack of political will to do so merely explain the inability of a system to hold its pieces together and the end result can lead to a failed state. To Jegede, insecurity in Nigeria, just like any developing society could have a compelling implications on a nation, thereby taking it back to a situation rightly described by Thomas Hobbes, one of the world's classic philosophers as nasty, bloody, brutish and short.

To a large extent, one can conclude by saying that Jegede's observations are scientific enough, hence they stand to prove a point namely, the increasing rate of violence and insecurity in Nigeria in recent times. Conversely, public functions are now being held amidst tight security and it appears that the Nigerian government has not only failed to secure its citizens; but also itself as a matter of constitutional responsibility (see Section 14(2c) of the Constitution of the Federal Republic of Nigeria, 1999 (as amended).

Lamenting on the current wave of insecurity in Nigeria, Okorie (2011) has claimed that Nigeria would not be able to tap into its $\$ 1.4$ trillion investment capital which circulates around the world as long as insecurity situation persists. The thrust of Okorie's arguments on Nigeria's slim chances of accessing Foreign Direct Investments as a result of insecurity is the need to re-examine and re-evaluate what rising insecurity portends to a struggling economy like Nigeria. Many examples that portrays the Nigerian state as struggling political entity can be seen in several incidences of poverty, insecurity, armed robbery, kidnapping, corruption in both high and low places, cultism, food shortages, just to mention but a few.

In the current Nigeria democracy however, two contending perspectives on the challenges of insecurity are prominent in most public discourses. There is the wobble economy, and corruption theses. The first example hinges on the downward spiral of the nation's economy as a result of the fall in prices of crude oil from about $\$ 140$ dollars to less than $\$ 39$ dollars per barrel. The increasing fall of oil prices at the international market, to most analysts is the direct consequences of the undue influence asserted by developed countries such as United States of America and Russia. It also borders on the inability of most oil-producing countries such as Saudi Arabia, Qatar, Iran, Iraq, etc, to honor the precepts and principles of restriction on the quota and volume of production of crude into the international market. The devastations caused by the oil glut has had untold hardship on the Nigerian economy long before the present government came on board. The nation is therefore worst hit due largely to the mono-cultural nature of the economic system and its over-reliance on oil resources as economic mainstay.

Besides the economic thesis as a major problem, corruption perspective seems much more problematic. Since inception of the APC led federal government in May, 29, 2015, several startling revelations have been made about how much public funds have been stolen through corrupt practices. The challenges of corruption are so much so that the difficulties associated with tackling Boko Haram since 2009 has been linked to it. From empirical evidence (see EFCC, 2016), several millions of dollars have been starched away by the leadership of the Peoples Democratic Party (PDP). It is particularly alleged that the then Security Adviser to President Jonathan, Sambo Dasuki gulped over \$2 trillion dollars meant for the procurement of fire arms for the efficient execution of war on terror. The investigation of the said case is still ongoing. This is outside several other cases that are yet unknown by the anti-graft commission, the Economic and Financial Crimes Commission (EFCC).

\section{Pre-disposing Factors to Insecurity in Nigeria}

A number of factors pre-dispose insecurity in Nigeria. These ranges from ethno-religious, economic and political factors to corruption and malicious media reports. 


\section{(a) Ethno-religious, Economic and Political Factors}

According to Ali (2013) cited in Olabayi and Ese (2014), the fear of insecurity in Nigeria is on the rise. Insecurity therefore has been compounded by the rising waves of terrorism, especially since the return of Nigeria from military dictatorship to democracy in 1999. The problem of violent crime appears to have a root and history in Nigeria and could be traced back to the period of Nigeria's independence in 1960 to the 1970s. Critics such as Ogbaga (2011) have argued that at independence in 1960, the present federal structure was imposed on Nigeria by the British. However, the federal structure bequeathed to Nigeria at independence did not conform to K.C. Wheare's tenets of federalism. To Wheare (1963), all the arms of government derive their constitutional powers from the constitution.

Thus, the intervention of military into governance and the subsequent imposition of military command structure set the pace for the distortions that was to be experienced in Nigeria's federalism. This is why Ewetan (2011) noted that:

The practice of federalism in Nigeria, no doubt, has been distorted by overwhelming dominance of the federal government that distributes national resources to lower level government at its own whims and caprices.

From Ewetan's claims about the arbitrary nature of the military autocracy as it relates to the distribution of resources, it therefore follows logically that since Nigeria's political independence, the demand for true federalism as well as fiscal and political restructuring by different ethnic nationalities in Nigeria has been on the increase (Boko Haram and Niger-Delta crisis inclusive). These kinds of agitations to Adamu (2005) and Ali (2013) have contributed to violent rebellions, reactions and counter reactions as exemplified by aggrieved ethnic groups in the country.

Ewetan and Ese (2014) claimed that, security challenges can be traced to the early years of the military rule when large quantities of arms were imported into Nigeria, especially for the execution of the civil war. Some of these weapons were believed to have gotten into the hands of the civilians. Soon after the civil war, these arms were used by civilians and ex-military men for mischievous purposes. There was the challenge of the army of unemployed youths some of whom lost their jobs during the civil war. Consequently, the level of insecurity assumed dangerous dimensions in the prolonged years of military rule beginning from 1970s during which people procured and kept arms and light weapons for personal defense purposes. Some of the arms are believed to have been diverted and placed in the hands of unemployed youths who used them for deviant purposes. Thus, while most researchers attribute youth violence to peer group influence and other psychological factors associated with young age, others harped on the impact of political and economic variables such as ethnic agitation, political uprising, unemployment concerns, Structural Adjustment Programme (SAP) and several other factors as compelling factors that could trigger violent reaction in the society.

However, many scholars such as Jega (2002), Lewis (2002), have warned that insecurity can be inimical to Nigeria's developmental processes in view of the adverse effects it could have on the nation generally. Hence, they have argued that the menace of insecurity can be both internal and external depending on the prevailing circumstances within a given time period. For the purpose of this study however, some of the internal factors will be considered. They include but not limited to the following:

\section{(b) Systemic Corruption}

The menace of systemic corruption in Nigeria has contributed no less a challenge to insecurity in the country. Corruption, especially at the level of government bureaucracy has been found to be chronic and the effect on the general psyche of the Nigerian system dangerous. It has contributed to government failure and breakdown of institutions as well as critical infrastructures. The state of insecurity in Nigeria at the moment is tremendously a function of government failure, traceable to systemic and political corruption. It has added another dimension of insecurity which has virtually eroded national values. According to Nwanaegbo and Odigbo (2013), corruption is bad not because money and other pecuniary benefits change hands, and certainly not because of the motives of participants, but because it privatizes valuable aspects of public life, by-passing processes of representation debate and choice.

\section{(c) Weak Security System}


One of the most critical factors bringing about insecurity in Nigeria is the fact that the nation's security system is weak. By security system, it means all other security networks, structures, technology and institutions that are essentially responsible for keeping the peace of the country. There are basically huge problems with the kind of security apparatus that is in operation in the country ranging from among other things, the structure of the military formation (except for the recent readjustment made); the police force, faulty recruitment processes and procedures, nepotism, corruption (in terms of embezzlement of funds meant for procurement of security gadgets/arms for prosecution of war on terror), compromise by security agents themselves in terms of how some of these weapons find their ways into wrong hands for wrongful usage order than the one of national interest and so on.

There are indeed reports in Nigeria where billions of naira meant for CCTV cameras were allegedly diverted by persons or groups in government. Some suspected or alleged that, the government simply embarked on importation of fake surveillance gadgets, decorate the major streets and places such as Abuja with little or no impact on the people entering and exiting the city center. This is the major reason why on several occasions terrorists had had a field day as exemplified by many cases of bomb explosions in the FCT area.

\section{(d) Illiteracy, Unemployment and Poverty}

It is observed that the incidence of illiteracy, unemployment and poverty which the practice of democracy since 1999 ought to have addressed is still alarming in the North. In fact, school enrollment is abysmally low in the Northern Region and the ratio is almost 7-3 compared to the Southern Region of the country. Abdulrazaq, Rohana \& Suyatno (2015) submitted that, "school enrolment in the South gets to some $70 \%$, while in the poverty-stricken North only some $30 \%$ go to school".

Literacy Survey of six (6) States sampled across the six (6) Geo-political zones in the federation revealed that: in the Northern part; NEBauchi has 39.5\%; NW-Kebbi 52.3\%; NC-Nasarawa 62.9\%; whereas, in the Southern part; SW-Lagos; 95.1\%; SE- Ebonyi 91.9\%; SSBayelsa; 93.8\% (NBS, 2010). In the country as a whole, the education index was 0.422 and the literacy rate was put at $60 \%$. Inadequate education was reflected by very poor scores of just 0.648 and by a school enrolment of $53 \%$, although government expenditure on education was $10 \%$ of the 2014 annual budget (BTI, 2014, cited in Abdulrazaq, Rohana \& Suyatno, 2015).

From the forgoing, the unemployment rate which was already high grows higher in the Fourth Republic. Unemployment implies state of joblessness, where some societal members lack sources of income which is necessary for their social, economic and political integration into the society (Adelekun, 2008, cited in Umar, 2009). Lack of employment, which in most cases is attributed to lack of education, normally breeds poverty amongst the youths. UNDP (2004) opined that, "the number of youths who are out of work and out of school either as graduates or drop-out -------are increasingly worrisome.” Again, the Department for International Development (2014) observed that, "Nigeria has a quarter of Africa's extreme poor, with about 100 million of a population of 174 million living on less than $£ 1$ a day". The incidence of poverty in Nigeria is quite alarming that an average man finds it difficult eating at least three square meals a day. The Northern zone was the worst hit with the North-Central zone recording 59.5\%; North-East 69\%, North-West 70\%; while, South-East was recording 58\%, South-South 55.9\% and South-West 49\% (NBS, 2012). This invariably indicated that Nigeria's democratic survival has serious challenge of tackling this ugly menace in order to get rid of terrorism and ensure national security. The connection between illiteracy, unemployment, poverty and terrorism/ insecurity in Northern zone of Nigeria cannot be ignored. Most terrorists are indoctrinated into the act due to illiteracy, unemployment and poverty that ravaged the area.

\section{(e) Malicious Media Reports}

This is when some media outfits disseminate fake news or give more priority to negative news as they do to the Nigerian security. For instance when Boko Haram stroke Baga in one of its devastating raids of Borno communities, an online media gave priority to the terrorists seeming sack of the military base of the multi-national joint task force. It proceeded to proclaim how the Nigeria military ignored intelligence reports warning of impending attack. Such floating details are unnecessary when national interest should be considered.

Again, another media reported the repeated terrorist attack on Biu, the country home of the Nigeria's Chief of Army Staff, Gen. Tukur Buratai, placing more emphasis on the symbolism of the penetration of the home of number one army officer. Biu is any body's community and the specifics of linking the town to chief of army staff alone was disingenuous and an attack on the efforts to tame national insecurity (Philip, 2016). 


\section{Concluding Remarks}

As stated earlier, the work has examined the menace of Boko Haram terrorism and Nigeria's national security concerns. As a result of the issues raised and analyzed in the study, we can conveniently draw conclusions on the strength of the following namely: the nature of policies and strategies enunciated and prosecuted by the government to curtail terrorism over the years have been the bane of security of the nation over time. That once the agent of state charged with the responsibility of maintaining peace and stability cannot perform its legitimate duty objectively, there is bound to be a problem such as that of Boko Haram terrorism. The failure of the media to objectively and broadly give information on issues, government policies and actions as well as enlighten the citizens on their roles in security matters has constituted part of the problems.

The analysis of this study shows that in order to ensure effective policies and strategies that can tackle insecurity, there is the need for re-evaluation of existing laws; ensure effective monitoring of such laws so as to allow those that have no clear cut impact on Nigeria's security architecture discarded. This will ensure that only workable legal system is upheld for overall success of the nation. Curbing insecurity in its entirety requires getting rid of all kinds of personal or group sentiments, mustering adequate political will and mobilizing efficient funds to execute total war on terrorism through renewed and robust security architecture. Illiteracy, unemployment and poverty must be fought headlong. The saying that education is the key to success is very germane. Illiterate, unemployed and poor population is susceptible to any form of violence. The statistics on the above issues indicated clearly why the North-East is in this quagmire. To ensure effective and sustainable security- revamping and improving economic activities leading to reduction in unemployment and poverty, increasing educational funding and improving school enrolment through various incentives are very necessary. Infrastructural development and policies that will encourage private sector investment which will in turn open up employment opportunities should be vigorously pursuit. Integrated poverty reduction programmes different from the existing ones should be instituted and sustained. Also, there must be genuine, total and all inclusive re-orientation and fight against corruption, vandalism and careless attitude towards public property. Disciplinary actions should henceforth be taken without sentiment on individuals who refuses to adhere to code of conduct. Anti-graft agencies should be proactive and rise up to this challenge at all levels of government. In this way, the desired objective of stemming the tides of insecurity will become a thing of the past.

The challenge of insurgency should not be seen as merely Nigerian problem, but should rather be conceptualized as African problem. This is the more reason why neighboring countries should give maximum support to Nigeria to be able to mitigate the dangerous activities of the dreaded sect both in Nigeria and its borders. To guarantee total and comprehensive destruction of Boko Haram stronghold, there should be a regional central command such as the building, maintenance and sustenance of powerful multinational military mechanism.

On its part, the media which is responsible for disseminating information to the public should place national interest above any parochial interest in reporting terrorism and other acts of violence against the people of Nigeria. It should also adhere to ethical and professional conducts such as balancing stories and reframing from reporting sensational or perceived views. Avoid any form of inducement or bribe from any quarter of the public or public agencies before or after news reportage. Nigeria Union of Journalists and National Broadcasting Commission should sanction erring members severely. And lastly, the mass media must avoid the temptation of over reporting negative news and under disseminating positive ones.

\section{References}

Abdulrazak,

Y.M, Rohana,

Y. and Nigeria's

Mediterranean

In Mediterranean Journal
Suyatno, Fourth Journal prospects. In Italy, MCSER publishing vol.6 no. 6 s4, Pp 445-451.

Abimbola, J.O. \& Adesote, S.A. (2012). Domestic Terrorism and Boko Haram Insurgency in Nigeria, Issues and Trends: A Historical Discourse. Journal of Arts and Contemporary Society, Vol 4.

Adehis, R. (2011) Insecurity in Nigeria: What Hope for the Common man? Leadership, Tuesday, p.31, October.

Adamu, A. (2005). True Federalism in the $21^{\text {st }}$ Century Nigeria. Being a public lecture series delivered at the University of Jos Alumni Association, Lagos, March 24.

Akinteriwan, B.A. (2001). US National Security and Nigeria. The Nigerian Voice Newspaper, p.2. 
Ali, A.D; (2013). Security and Economic Development in Nigeria Since 1960. Kuwait Chapter of Arabian Journal of Business and Management Review 2(6).

Arena, M.P. and Arigo, B.A. (2006). The Terrorist Identity: Explaining the Terrorist Threat. New York and London: New York University Press.

Awortu, B.E. (2015). Boko Haram Insurgency and the Underdevelopment of Nigeria. Research on Humanities and Social Sciences, $5(6)$.

Ewetan, O. O. \& Nse, U. (2014). Insecurity and Socio-economic Development in Nigeria. In Journal of Sustainable Development Studies, Vol. $5(1)$

Gbanite, M. (2001). National Security and Intelligence in Nigeria under a Democracy: the Way forward. This Next News, P.4

Lewis, P. M. (2002). Islam, Protest and Conflict in Nigeria. Washington Centre for Strategic and International Studies (CSIS), Africa Notes, No. 10

Momoh, J. (2016). Information as a Tool for National Security: Role of the Media. Being Paper Presented at the National Defence College, Abuja, January 13.

NBS, (2010). National www.nigerianstat.gov.ng/papes/downloads/43

NBS, (2012). Annual Abstract Literacy Survey. Retrieved 27/08/2014@

Transparency International (2013). Corruption Statistics. Abuja: NBS Publishers 10/09/2018@www.transparency.org

Nwagboso, C. I. (2010). Security Challenges and Economy of the Nigerian State,

2007-2011. In American Journal of Contemporary Research, Vol.2(6)

Okorie, I. (2011). Insecurity Consequencies for Investiment and Employment, Punch Newspaper, Thursday, sept. 9, Pp. 37-38

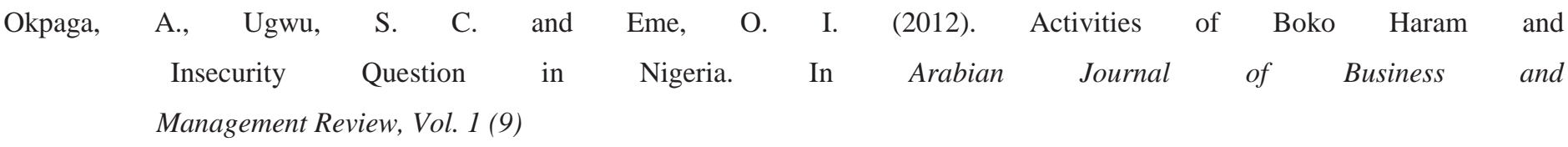

Oyebode, A. (2011). The Imperative of Security. The National Scholar. Vol. 8 (2)

Philip, A. (2016). Terrorism, National Security and the Mass Media. Daily Trust, September 29.

Tajfel, H. \& Turner, J. C. (1985). The Social Identity Theory of intergroup Behaviour. In S. Worchel \& W. G. Austin (eds) Psychology of Intergroup Relations. Chicago: Nelson Hall

Umar S. U. (2009). Youths and Political Thuggery in Nigeria. In Nigerian Journal of Social Research. Vol.1, No.3. Faculty of Social Sciences, Nasarawa State University, Keffi.

Williams, P.D. (2008). Security Studies: an Introduction. New York: Routledge. 